\title{
APPLICATION OF THE STOCHASTIC PROFIT FRONTIER MODEL TO ESTIMATE ECONOMIC EFFICIENCY IN SMALL-SCALE BROILER PRODUCTION IN THE GREATER ACCRA REGION OF GHANA
}

\author{
Raymond K. DZIWORNU ${ }^{1 *}$, Daniel B. SARPONG ${ }^{2}$
}

\begin{abstract}
Address:
${ }^{1}$ Department of Banking and Finance, University of Professional Studies, P. O. Box LG 149, Accra, Ghana.

${ }^{2}$ Department of Agricultural Economics \& Agribusiness, College of Agriculture and Consumer Sciences, University of Ghana, Legon.

*Corresponding author: Raymond K. Dziwornu, e-mail: dziray28@yahoo.com
\end{abstract}

\begin{abstract}
This paper applied the stochastic profit frontier model to estimate economic efficiency of 199 small-scale commercial broiler producers in the Greater Accra Region of Ghana. Farm-level data was obtained from the producers through a multi-stage sampling technique. Results indicate that broiler producers are not fully economically efficient. The mean economic efficiency was 69 percent, implying that opportunity exist for broiler producers to increase their economic efficiency level through better use of available resources. Age of producer, extension contact, market age of broiler and credit access were found to significantly influence economic efficiency in broiler production. Policy measures directed at these factors to enhance economic efficiency of broiler producers are recommendable.
\end{abstract}

Keywords: economic efficiency, stochastic profit frontier, broiler production, Ghana.

JEL: Q1, Q12, Q120

\section{INTRODUCTION}

The efficiency of resource use is an important factor that determines the performance of an enterprise. It is the act of achieving a given result such as profit with minimal waste. In recent years, studies on efficiency in agricultural production have become an important issue to economists and policy makers who are concerned with the problems in developing countries (Chowdhury, 2010; Musa et al., 2011). This is because efficiency is a factor of productivity growth, especially in developing economies where resources are meagre and opportunities for developing and adopting better technologies are declining (Ali and Chaudhry, 1990). With the low technology adoption challenge facing agricultural growth improving the efficiency of resource use remains the most cost effective way to enhance agricultural productivity in developing countries like in Ghana.

Commercial broiler production used to be a vibrant agricultural enterprise in Ghana, supplying about 95 percent of total domestic poultry meat requirement of the country and providing employment opportunities as well as high quality protein meat for Ghanaians. However, since the mid 1990s the share of domestic broiler production in total market demand has been on the decline. Domestic broiler production can now satisfy only 11 percent of total domestic demand, with the excess demand met by imports (Randan and Ashitey, 2011). Ghana now imports over 80,000 metric tons of poultry meat to meet the increasing domestic demand. The decline in domestic broiler share has been attributed to competition from cheap poultry imports that have more than quadruple between 2000 and 2008 as well as changes in government policies such as removal of government support for drug costs, discontinuation of government importation and support for feed mill ingredients and reduction of preference in interest rates for agricultural credit (Nkansala, 2004). These factors have raised the cost of broiler production by over 60 percent, resulting in many large enterprises folding up, while others have gone into mainly egg production. To help revive the broiler sector, governments adopted many policies such as the importation and sale of $20,000 \mathrm{Mt}$ of yellow maize in 2005 to poultry farmers to boost local production and facilitating the capitalization and marketing of broiler birds through a joint Government and Agricultural development Bank broiler out grower scheme in 2003 (MOFA, 2010). Despite these efforts, growth in domestic broiler production in Ghana still remains low, raising efficiency concerns. There is the need for broiler producers to utilize their resources much more efficiently to increase production, even before considering additional investment in the sector.

Several studies have examined efficiency in agriculture production by employing two main approaches: the parametric Stochastic Frontier Analysis (Coelli and Battese, 1996) and non-parametric Data Envelopment Analysis (Begum et. al., 2009) techniques. Studies that applied the stochastic frontier analysis used the traditional production function approach (Amaza and Maurice, 2005; Egbetokum and Ajijola, 2008). In Ghana, the stochastic production frontier method has been applied to fish farming (Onumah et. al., 2010), rice (Seidu, 2008), vegetable (Peprah, 2010) and cocoa 
(Dzene, 2010) productions, but not in broiler production. These studies focused only on technical efficiency and not economic efficiency which also includes allocative efficiency. Meanwhile, it is possible for a farmer to achieve technical efficiency, though at a much higher cost. Abdulai and Huffman (1998) however applied the profit frontier model to estimate farm-level efficiency in rice production in Northern Ghana. To the best of our knowledge, no empirical study has been undertaken to apply the stochastic profit frontier model to examine economic efficiency in broiler production in Ghana. This study therefore applied the stochastic profit frontier model to estimate economic efficiency in small-scale broiler production in the Greater Accra Region of Ghana.

The rest of the paper is presented as follows: The next section presents a discussion of the theoretical framework underpinning the study. The study area, data, sampling process and empirical model are then discussed and presented. This is followed by a discussion of the empirical results, conclusions and recommendations to improve economic efficiency in broiler production.

\section{The Stochastic Profit Frontier Model}

Theoretical measurement of efficiency was first developed by Farrell (1957) when he identified technical, allocative and economic efficiencies. Traditionally, the production function technology is popularly used to measure efficiency components (Tzouvelekas et. al., 2001; Wadud and White, 2000). In this framework, a farm is said to be technically inefficient for a given set of inputs if its output level lies below the maximum feasible output. Also, a farm is allocatively inefficient if it is not using inputs in optimal proportion. In a profit maximizing framework, a farm can also be scale inefficient if it is not producing at output level that equates the product price with the marginal cost (Kumbhakar et. al., 1989). However, Ali and Flinn (1989) have argued that the production function framework fails to capture inefficiencies associated with different factor endowments and input and output prices across farms. As a result farms may exhibit different "best practice" production functions and operate at different optimal points. This led to the popularization and use of the more flexible profit function model to directly estimate farm-specific efficiency (Kumbhakar, 2001; Wang et al., 1996). The profit function framework combines technical, allocative and scale efficiency measures into one system and enables more efficient estimates to be obtained by simultaneous estimation of the system. Any errors in production decision are assumed to be translated into lower producer profits (Ali et. al., 1994). Unlike the production function, the profit function model considers the ratio of relative input and output prices that accounts for allocative efficiency. Economic efficiency is therefore defined as the ability of a farm to achieve the highest possible profit, given the prices and levels of fixed factors of that farm.

In the estimation of the stochastic frontier model, two procedures are normally used: two-stage and onestage. In the two-stage procedure, the predicted efficiency scores are regressed against a number of household farm characteristics to explain the observed differences in efficiency among farms. Although this procedure has been recognized as a useful one, it has also been criticized as one which is inconsistent in its assumptions regarding the independence of the inefficiency effects (Coelli, 1996). In the second procedure called one-step estimation, all the parameters are obtained in one step. The inefficiency effects are defined as a function of the farm specific factors but are then incorporated directly into the Maximum Likelihood Estimation (MLE). Both the production frontier and the inefficiency effect models are simultaneously estimated. Battese and Coelli (1995) extended the stochastic production frontier model by suggesting that inefficiency effects can be expressed as a linear function of explanatory variables. The advantage of this model is that it allows for the estimation of farm specific efficiency scores and factors explaining efficiency differentials among farmers in a single stage estimation procedure. This study utilized Battese and Coelli (1995) model by formulating a profit function assumed to behave in the manner consistent with the stochastic frontier model.

The stochastic profit frontier model is therefore defined as:

$\ln \pi=f\left(P_{i}, Z_{i}\right), \operatorname{esp}\left(\varepsilon_{i}\right)$, where $\quad \varepsilon_{i}=V_{i}-U_{i}$

where $i=1, \ldots, n$ is the number of farms in the sample, $\pi_{i}$ is normalized profit of the $i^{\text {th }}$ farm defined as gross revenue less variable cost, divided by farm-specific output price; $P_{i}$ is the vector of variable input prices faced by the $i^{\text {th }}$ farm divided by output price; $Z_{i}$ is the vector of fixed factor of the $i^{\text {th }}$ farm; $\varepsilon_{i}$ is an error term that is assumed to behave in a manner consistent with the frontier concept. $v_{i} \mathrm{~s}$ are assumed to be independently and identically distributed $N\left(0, \sigma_{v}^{2}\right)$ two sided random errors, the $u_{i}$ s are non-negative random variables associated with inefficiency in production, which are assumed to be independently distributed as truncations at zero $(0)$ of the normal distribution with mean, $u_{i}=\delta_{o}+\sum_{d} \delta_{d} W_{d i}$ and variance $\sigma_{u}^{2}\left(\left|\mathrm{~N}\left(\mu_{i}, \sigma^{2}{ }_{u}\right)\right|\right)$, where $W_{d i}$ is the $d^{\text {th }}$ explanatory variable associated with inefficiencies on farm $i$ and $\delta_{o}$ and $\delta_{d}$ are the unknown parameters. The economic efficiency of farm $i$ in this framework is defined as:

$$
\begin{aligned}
& E E F_{i}=E\left[\exp \left(-U_{i}\right) \mid \varepsilon_{i}\right]=E\left[\operatorname{esp}\left(-\delta_{o}-\sum \delta_{d} W_{d i}\right) \mid\right. \\
& \left.\varepsilon_{j}\right]
\end{aligned}
$$

Where $E E F$ is the economic efficiency of farm $i$ and $E$ the expectation operator, is achieved by obtaining the expressions for the conditional expectation $u_{i}$ upon the observed value of $\varepsilon_{i}$. The maximum likelihood estimation method is used to estimate the unknown parameters, with the stochastic profit frontier and the inefficiency effects functions estimated simultaneously. The likelihood function is expressed in terms of the variance parameters as: $\sigma^{2}=\sigma_{v}^{2}+\sigma_{u}^{2}$ and $\gamma=\sigma_{u}^{2} / \sigma^{2}$ (Battese and Coelli, 1995). 


\section{MATERIAL AND METHODS}

This study was carried out in the Greater Accra Region of Ghana, where large commercial broiler production takes place. The Greater Accra Region is found on the coastal belt of Ghana and lies between longitudes $1^{\circ} 8^{\prime} \mathrm{E}$ $-0^{\circ} 30 \mathrm{~W}$ and latitude $5^{\circ} 70^{\prime}-6^{\circ} 8^{\prime} \mathrm{N}$ of the equator and has a total land size of 3.24 thousand square kilometres.

A multi-stage sampling technique was used to select and interview 200 small-scale commercial broiler producers who are members of the Greater Accra Poultry Farmers Association (GAPFA). Small-scale broiler producers are defined as farmers with stock size of between $50-5000$ birds per batch and using the deep litter system of production. Purposive sampling method was used in the first stage to select the region. Officials of the GAPFA were interviewed to identify the Districts and Communities where commercial broiler production is mainly undertaken. Five (5) districts were selected from the region (Accra, Tema Metropolis, GA East, GA West and Damgbe West). Two communities were then selected from each district to obtain a total of 10. Since small-scale broiler producers are not evenly distributed within the communities, simple random sampling was finally applied to select 200 broiler producers in a ratio proportional to their population. Effort was made to include in the sample small-scale broiler producers that the GAPFA believes are making optimal profit share of at least 40 percent. Although 200 small-scale broiler producers were visited and personally interviewed, 199 questionnaires were used for the analysis.

Data on input and output quantities as well as prices for the 2010 production cycle were collected with the aid of structured questionnaire. The questionnaire which was pre-texted consisted of both open-ended and close ended questions as well as yes and no questions.

\section{Empirical Model Specification}

Following Battese and Coelli (1995) framework, a modified stochastic Cobb-Douglas profit frontier model with inefficiency effect component behavior was used for the study. The explicit form of the stochastic profit frontier model used in the study is specified as:

$$
\begin{aligned}
& \ln \pi_{i}=\beta_{o}+\beta_{1} D H L_{1}+\beta_{2} D F L_{2}+\sum_{i=3}^{9} \beta_{i} \ln P_{i}+ \\
& V_{i}+U_{i}
\end{aligned}
$$

Where $\boldsymbol{P}_{3}$ is the price of day-old chick normalized by farm-specific price of broiler and then re-scaled by its sample mean; $\boldsymbol{P}_{4}$ is the price of feed $(\mathrm{kg})$ normalized by farm specific price of broiler and then re-scaled by its sample mean; $\boldsymbol{P}_{\boldsymbol{5}}$ is the wage rate of hired labour per man-day normalized by farm-specific price of broiler and then re-scaled by its sample mean; $\boldsymbol{P}_{\boldsymbol{6}}$ is the imputedwage rate of family labour per man-day, normalized by farm-specific price of broiler and re-scaled by its sample mean; $\boldsymbol{P}_{7}$ and $\boldsymbol{P}_{\boldsymbol{s}}$ are the prices of medication and vaccines and other variable inputs respectively, both normalized by farm-specific price of broiler and then re-scaled by their respective normalized price sample means; $\boldsymbol{P}_{\boldsymbol{g}}$ is the per bird depreciation value of capital used on the farm in a batch. The straight line method was used to determine the depreciation value of farm building and equipment in a batch. $\boldsymbol{\beta}_{\boldsymbol{o}}, \boldsymbol{\beta}_{1}, \boldsymbol{\beta}_{2}, . . \boldsymbol{\beta}_{9}$ are parameters to be estimated and are expected to have a negative sign. $\boldsymbol{D H} \boldsymbol{H}_{\boldsymbol{I}}$ and $\boldsymbol{D F} \boldsymbol{L}_{2}$ are dummy variables for hired and family labour respectively. In order to solve the problem of zero observations of wage rate of hired and imputed family labour encountered in the data for estimation, the study set the log-value of the zero-observations of the cost of these two sources of labour to be zero with dummy variables to explicitly examine their effect on profit. This procedure ensures that efficient estimators are obtained using the full data set without introducing any bias. $D H L_{I}$ and $D F L_{2}$ are therefore dummy variables equal to one if there is wage rate for hired labour and imputed-wage rate for family labour and zero otherwise. These dummy variables capture intercept change effect of wage rate of hired and family labour. The estimator for profit responsiveness to changes in wage of hired and family labour would be bias without the inclusion of $D H L$ and DFL (Battese, 1997).

The empirical economic efficiency model estimated is specified as:

$$
\begin{aligned}
& U_{i}=\delta_{0}+\delta_{1} A G E_{i}+\delta_{2} \operatorname{EXTCON}_{i}+\delta_{3} \text { MKTAGE }_{i}+ \\
& \delta_{4} \operatorname{CRDACC}_{i}+e_{i}
\end{aligned}
$$

Where $\boldsymbol{\delta}_{i}$ are parameters to be estimated, $\operatorname{Exp}\left(-U_{i}\right)$ is the farm level economic efficiency of the $i^{\text {th }}$ farm and $e_{i}$ is an error term that follows a truncated normal distribution. AGE is broiler producer's age; EXTCON is number of extension contacts in a batch; MKTAGE is market age of broiler measured as the deviation from the standard 56 days required for birds to be ready for market; ACCRDT is a dummy variable indicating whether or not farmer had access to credit. The parameter estimates of the stochastic profit frontier and inefficiency effect models were simultaneously obtained through a single stage maximum likelihood estimation method, using the computer software FRONTIER 4.1 (Coelli, 1996b).

The test for the presence of economic inefficiency using generalized likelihood-ratio statistics $\lambda$ is defined by: $\lambda=-2\left[\operatorname{In} \mathrm{L}\left(\mathrm{H}_{\mathrm{o}}\right)-\operatorname{In} \mathrm{L}\left(\mathrm{H}_{\mathrm{a}}\right)\right]$. Where: $\mathrm{H}_{\mathrm{o}}$ is the value of the likelihood function for the frontier model in which parameters restriction specified by the null hypothesis, $\mathrm{H}_{\mathrm{o}}$ are imposed; and $\mathrm{H}_{\mathrm{a}}$ is the value of the likelihood function for general frontier model. If the null hypothesis is true then $\lambda$ has approximately a mixed chi-square distribution with degree of freedom equal to the number of parameters excluded in the unrestricted model. The critical value for the hypothesis involving $\gamma$ was obtained from Kodde and Palm (1986).

\section{RESULTS AND DISCUSSION}

\section{Descriptive statistics of socio-economic variables}

The descriptive statistics of the socio-economic characteristics of small-scale commercial broiler producers sampled is presented in Table 1. The average age of small-scale broiler producers sampled is about 43 years, suggesting that producers are young adult in the 
study area. About 56 percent of broiler producers interviewed are into full time broiler production with an average stock size of 661 birds per batch. Increasing birds stock per batch will ensure broiler producers enjoy economies of scale to be more profitable. There is the need to encourage and support the youth to go into full time large-scale commercial broiler production to address the increasing unemployment in the country. The average extension service contact received by the average producer is less than two visits per batch. The capacity of broiler producers need to be built through more extension service contacts to ensure they adopt proper farm management practices. The result further shows an average broiler market age of 60 days that is higher than the standard 42-56 days required for matured broilers to be ready for the market. Broiler producers need to feed their birds with high quality and nutritious feed to enable birds gain the right market weight by week eight.

Table 1: Descriptive statistics of socio-economic characteristics of small-scale broiler producers

\begin{tabular}{|c|c|c|c|c|}
\hline $\begin{array}{l}\text { Variable per } \\
\text { bird/batch }\end{array}$ & Mean & Min & Max & St. Dev \\
\hline Gross profit $(\mathrm{GH} \phi)$ & 6.18 & 0.4 & 21.22 & 3.82 \\
\hline $\begin{array}{l}\text { Farm size (No. of } \\
\text { birds stocked) }\end{array}$ & 661 & 50 & 4500 & 633 \\
\hline $\begin{array}{l}\text { Broiler output } \\
\text { (No. of birds) }\end{array}$ & 637 & 45 & 4500 & 616 \\
\hline $\begin{array}{l}\text { Price of matured } \\
\text { broiler }(\mathrm{GH} \phi)\end{array}$ & 16.40 & 10 & 30 & 3.08 \\
\hline $\begin{array}{l}\text { Price of day-old } \\
\text { chick }(\mathrm{GH} \phi)\end{array}$ & 2.07 & 1.2 & 3 & 0.35 \\
\hline $\begin{array}{l}\text { Price of feed } / \mathrm{kg} \\
(\mathrm{GH} \phi)\end{array}$ & 4.09 & 1.32 & 11.2 & 1.62 \\
\hline $\begin{array}{l}\text { Wage of hired } \\
\text { Labour }(\mathrm{GH} \phi)\end{array}$ & 1.56 & 0 & 9.33 & 1.86 \\
\hline $\begin{array}{l}\text { Imputed wage of } \\
\text { family Lab. }(\mathrm{GH} \phi)\end{array}$ & 0.69 & 0 & 9.17 & 1.48 \\
\hline $\begin{array}{l}\text { Cost of } \\
\text { medication/vaccine }\end{array}$ & 0.38 & 0.11 & 1.57 & 0.21 \\
\hline $\begin{array}{l}\text { Other operating cost } \\
(\mathrm{GH} \notin)\end{array}$ & 0.65 & 0.09 & 2.21 & 0.43 \\
\hline $\begin{array}{l}\text { Capital input Cost } \\
(\mathrm{GH} \phi)\end{array}$ & 0.38 & 0 & 3.08 & 0.42 \\
\hline $\begin{array}{l}\text { Age of farmer } \\
\text { (years) }\end{array}$ & 42.56 & 24 & 74 & 10.97 \\
\hline Full Time & 0.56 & 0 & 1 & 0.5 \\
\hline $\begin{array}{l}\text { Extension service } \\
\text { contacts/batch }\end{array}$ & 1.32 & 0 & 5 & 0.71 \\
\hline $\begin{array}{l}\text { Market Age of } \\
\text { broilers }\end{array}$ & 59.45 & 28 & 77 & 11.83 \\
\hline Credit Access & 0.17 & 0 & 1 & 0.37 \\
\hline
\end{tabular}

By selling a matured broiler at market age for GH $\notin 16.40$, the result shows that small-scale broiler producers make a gross profit of GHф6.18 per bird. Broiler producers could sell their product at a competitive price to make more profit if the cost of broiler production is reduced. Of the total variable cost of production, feed and day-old chick costs together constitute about 66 percent in the study area. This indicates the importance of these two inputs in broiler production. With the increasing cost of feed in recent times, broiler producers need to efficiently utilize feed resources to reduce expenditure on feed to increase profitability. In addition, producers need to use breeds of chicks that are good converters of feed and resistant to diseases to enable them maximize feed utilization.

\section{Maximum Likelihood Estimation Regression Results}

The maximum likelihood estimation result of the modified normalized stochastic Cobb-Douglas profit frontier model is presented in Table 2. Since gross profit per bird and input prices were re-scaled by their respective sample mean, the first order coefficient of the parameters can be interpreted as profit elasticities. This measures the responsiveness of profit of small-scale broiler producers to changes in broiler input prices. With the exception of medication and vaccines variable which was not significant, the coefficients of all the other variables have the expected sign and are significant at 1 percent. This indicates that the estimated normalized Cobb-Douglas profit function is non-increasing in input prices. Reducing the cost of these variable inputs, especially feed and day-old chick, will significantly increase profitability in broiler production. This result corroborates Ike and Ugwumba (2011) who found feed and day-old chick cost to be the two most important factors affecting profit of small-scale broiler farmers in their study. The sum of elasticities of the variable input prices is 0.90 , suggesting that a 1 percent decrease in all variable input prices will increase profit by 0.90 percent. The diagnostic statistics of the stochastic profit frontier model showed a total variance of 0.93 and statistically significant at 1 percent level. The variance ratio $(\gamma)$ is also significant at 1 percent, indicating that 99.9 percent of disturbance in the stochastic profit frontier model is due to economic inefficiency of small-scale broiler producers, with the remaining 0.10 percent due to noise effect. The log-likelihood function value of the parameter estimates is - 41.66, while the LR test statistics of the one sided error is 115.10 and significant at 1 percent.

The result of the null hypotheses test for the absence of economic inefficiency effects $\left(H o: \gamma=\delta_{0}=\delta_{I}\right.$ $\left.=\ldots \delta_{4}=0\right)$ and that inefficiency effects are not stochastic $(H o: \gamma=0)$ are all rejected at 1 percent level of significance. This indicates that the traditional average (OLS) function is not an adequate representation for the result and also that economic inefficiency exist in small scale broiler production and are indeed stochastic. A joint test of the dummy variables of the wage rate of hired and imputed family labour was also rejected. This indicates that wage rate of hired and family labours significantly affect profits of small-scale broiler producers. Their intercept coefficients are both negative and significant at 1 percent. The estimates of the wage rates of hired labour and imputed-wage of family labour in the stochastic Cobb-Douglas profit frontier model would have been biased without the inclusion of these dummies.

The economic efficiency scores distribution as presented in Table 4 shows that about forty percent of small-scale broiler producers sampled have economic efficiency score that suggests they are operating at 80 percent or more of their potential based on the estimated 
economic efficiency frontier. While the maximum economic efficiency score is 99 percent, the minimum score is 8.7 percent. The mean efficiency score is about 69 percent, suggesting that potential for improving economic efficiency exists among small-scale broiler producers. The small-scale broiler producer is therefore not fully economically efficient. If the average smallscale commercial broiler producer with average efficiency increases its efficiency to that of the most efficient producer in the sample, it could realize about 31 percent saving in costs. Efforts to improve both technical and allocative inefficiencies of small-scale broiler producers not operating close to the profit frontier would be essential to ensure efficient resource utilization to achieve the maximum feasible profit.

Table 2: Stochastic Cobb-Douglas Profit Frontier Model Parameter Estimates

\begin{tabular}{|c|c|c|c|}
\hline Variables & Parameter & Coefficients & $\begin{array}{r}\begin{array}{r}\text { Standard } \\
\text { error }\end{array} \\
\end{array}$ \\
\hline Constant term & $\beta_{0}$ & $0.338 * * *$ & 0.037 \\
\hline DHL & $\beta_{1}$ & $-0.140 * * *$ & 0.018 \\
\hline DFL & $\beta_{2}$ & $-0.174 * * *$ & 0.013 \\
\hline Price of DOC & $\beta_{3}$ & $-0.267 * * *$ & 0.048 \\
\hline Price of Feed & $\beta_{4}$ & $-0.278 * * *$ & 0.018 \\
\hline $\begin{array}{l}\text { Wage of hired } \\
\text { Labour }\end{array}$ & $\beta_{5}$ & $-0.153 * * *$ & 0.008 \\
\hline $\begin{array}{l}\text { Imputed wage } \\
\text { of Family labour }\end{array}$ & $\beta_{6}$ & $-0.094 * * *$ & 0.011 \\
\hline Price of Med/Drugs & $\beta_{7}$ & -0.04 & 0.029 \\
\hline Other Cost & $\beta_{8}$ & $-0.066^{* * *}$ & 0.002 \\
\hline Capital input Cost & $\beta_{9}$ & $-0.007 * * *$ & 0.009 \\
\hline \multicolumn{4}{|l|}{ Diagnostic Statistics } \\
\hline $\begin{array}{l}\text { Log-likelihood } \\
\text { function }\end{array}$ & & -41.66 & \\
\hline Total Variance & $\sigma^{2}$ & $0.933 * * *$ & 0.22 \\
\hline Variance ratio (Gamma) & $\gamma$ & $0.999 * * *$ & 0.064 \\
\hline LR test statistic & & & 115.1 \\
\hline
\end{tabular}

Table 3: Log-Likelihood Ratio Test of Null Hypotheses

\begin{tabular}{lrrr}
\multicolumn{1}{c}{ Null Hypothesis } & $\begin{array}{r}\text { Test } \\
\text { Statistic }(\lambda)\end{array}$ & $\begin{array}{r}\text { Critical value } \\
(0.001)\end{array}$ & Decision \\
\hline $\begin{array}{l}\text { Ho: } \gamma=\delta_{0}=\delta_{1}=\ldots \\
\delta_{4}=0\end{array}$ & 86.98 & 21.67 & $\begin{array}{r}\text { Reject } \\
\text { Ho }\end{array}$ \\
Ho: $\gamma=0$ & 115.1 & 9.5 & $\begin{array}{r}\text { Reject } \\
\text { Ho }\end{array}$ \\
Ho: $\beta_{1}=\beta_{2}=0$ & 15.2 & 13.82 & $\begin{array}{r}\text { Reject } \\
\text { Ho }\end{array}$ \\
\hline
\end{tabular}

Source: Survey Data, 2010. The values of one sided error from the profit frontier and critical value were obtained from Table 1, Kodde and Palm (1986), pp. 1246 and significant at 0.001 level.

Determinants of farm-specific economic efficiency of small-scale broiler Producers

Table 5 presents the results of the factors that explain variation in economic efficiency among small-scale broiler producers sampled. Considering the way equation 4 is stated, a variable with negative sign coefficient means it is positively related to economic efficiency and vice versa. In this regard, age of broiler producer, extension service contact, market age of broilers and access to credit were found to be the main factors that significantly explain variation in economic efficiency of small-scale broiler producers. Age of broiler producer is positive and statistically significant at 1 percent, implying a negative influence on economic efficiency. This means younger broiler producers are more economically efficient than older producers. Younger producers take more risk and are innovate to produce more efficiently than older producers. They are also more receptive to new ideas or technology than older ones. Effiong and Onyenweaku (2006) found age to positively influence economic efficiency.

Table 4: Distribution of economic efficiency scores of small scale broiler producers

\begin{tabular}{lrrr}
\hline $\begin{array}{l}\text { Production Efficiency } \\
\text { Scores }\end{array}$ & Mean & Frequency & Percentage (\%) \\
\hline Less than 0.30 & 0.199 & 18 & 9 \\
$0.30-0.39$ & 0.341 & 12 & 6 \\
$0.40-0.49$ & 0.45 & 12 & 6 \\
$0.50-0.59$ & 0.555 & 17 & 8.5 \\
$0.60-0.69$ & 0.656 & 24 & 12.1 \\
$0.70-0.79$ & 0.751 & 36 & 18.1 \\
$0.80-0.89$ & 0.845 & 45 & 22.6 \\
$0.90-0.99$ & 0.953 & 35 & 17.6 \\
Total & & 199 & 100 \\
Mean & 0.687 & & \\
Minimum & 0.087 & & \\
Maximum & 0.999 & & \\
Standard Deviation & 0.232 & & \\
Source: Survey Data, 2010 & & & \\
& & &
\end{tabular}

Table 5: Determinants of economic efficiency of Smallscale broiler producers

\begin{tabular}{lcrr}
\hline Variables & Parameter & Coefficients & $\begin{array}{r}\text { Standard } \\
\text { error }\end{array}$ \\
\hline Constant term & $\delta_{0}$ & $-4.692^{* * *}$ & 1.344 \\
Age & $\delta_{1}$ & $0.051^{* * *}$ & 0.006 \\
Extension service & $\delta_{2}$ & $-0.187^{* * *}$ & 0.087 \\
contact & & & \\
Market Age of & $\delta_{3}$ & $0.265^{* * *}$ & 0.006
\end{tabular}

broiler

$\begin{array}{llll}\text { Access to credit } & \delta_{4} & -0.688 * * * & 0.19\end{array}$

Source: Survey Data, 2010. *** indicates 1 percent, significance level

The coefficient of extension service contact variable is negative and statistically significant at 1 percent, indicating a positive influence on economic efficiency. The more extension service contacts a broiler producer has the more economically efficient it becomes. Small-scale commercial broiler producers who receive more extension service contacts get advisory services and technical know-how that builds their capacity in broiler production. They are therefore able to produce better and to become more efficiently than those who do not. This result is consistent with Ohajianya (2005) and Rahman (2003) who found extension service contact to explain economic efficiency of farmers in their studies.

Market age variable has a positive coefficient and statistically significant at 1 percent, indicating a negative influence on economic efficiency. Small-scale broiler producers who deviate more from the standard 56 days required for broilers to be ready for market are less 
economically efficient than producers who deviate less from the required days. Keeping birds beyond 56 days means extra cost of production for the additional days. Besides, the feed efficiency of broiler also deteriorates when they get older as more quantities of feed are needed to maintain their body mass. Broiler producers need to feed birds with balanced and nutritious feed to ensure birds gain the right market weight by week eight. This will ensure efficient use of feed resources to reduce expenditure on feed for producers to be economically efficient. This result is consistent with Schmidt (2008) who found market age to negatively affect economic efficiency in broiler production in his study.

Finally, access to credit variable has a negative coefficient and statistically significant at 1 percent, suggesting a positive influence on economic efficiency. Small-scale broiler producers who have access to credit to produce are more economically efficient than those who do not have access to credit. Access to credit eases financial constraints in broiler farming and also enhances the acquisition of inputs such as feed. Therefore, broiler producers who have access to credit are able to buy inputs in bulk, finance and expand their operations to enjoy economies of scale to be efficient. Abu and Asember (2011) also found credit access to have positive influence on efficiency in their study.

\section{CONCLUSIONS AND POLICY IMPLICATIONS}

This study applied the stochastic profit frontier model to examine economic efficiency of 199 small-scale commercial broiler producers in the Greater Accra of Ghana. The result shows that profit of small-scale broiler producers is highly responsive to changes in feed and day-old chick prices. Reducing prices of these two inputs will significantly increase profits in broiler production. Small-scale broiler producers sampled are not fully economically efficient. Opportunity exists to increase economic efficiency of broiler producers by about 31 percent without changing the profit frontier. Age of broiler producers, extension service contact, market age at which broilers are ready for market as well as access to credit are the main factors that significantly influence economic efficiency of small-scale broiler producers. Appropriate policy measures directed at these factors will significantly enhance economic efficiency in broiler production. Capacity of broiler producers should be built through regular seminars and workshops to enable them adopt proper farm management practices to improve their economic efficiency. Broiler producers should also feed their birds with nutritious feed to enable birds gain the right market weight by week eight. Credit at preferential rate lower than the market rate should be made available to broiler producers. Above all, the youth should be encouraged and supported to go into broiler production to reduce youth unemployment in the country.

Acknowledgments: The authors are very grateful for the assistance and support of Sena Amewu, Kingsley Anagba, Anthony Acquah and Nutifafa Komladzie as well as small-scale commercial broiler producers in the
Greater Accra Region of Ghana for providing us with information concerning their businesses for this study.

\section{REFERENCES}

ABDULAI, A.- HUFFMAN, W. 1998. An examination of Profit Efficiency of Rice Farmers in Northern Ghana. Iowa State University, Department of Economics, Staff papers, No. 296. Available at: http://ageconsearch.umn.edu/bitstream/18271/1/isu296.p df

ABU, O. - ASEMBER, D. J. 2011. Opportunities for Smallholder Farmers in Nigeria, A Profit Efficiency Analysis. Journal of Economics, 2(2): 75 - 79. Available at: http://www.krepublishers.com/02-Journals/JE/JE-020-000-11-Web/JE-02-2-000-11-Abst-PDF/JE-02-2-07511-083-Abu-O/JE-02-2-075-11-083-Abu-O-Tt.pdf ALI, M.- CHAUDHRY, M. A. 1990. Inter-regional Farm Efficiency in Pakistan's Punjab. A Frontier Production Function Study. Journal of Agricultural Economics, 41:62 - 73. http://dx.doi.org/10.1111/j.14779552.1990.tb00619.x

ALI, M.- FLINN, J. C. 1989. Profit Efficiency among Basmati Rice Producers in Pakistan Punjab. American Journal of Agricultural Economics, 71, 303-310. http://dx.doi.org/10.2307/1241587

ALI F.- PARIKH, A.- SHAH, M. K. 1994. Measurement of Profit Efficiency using Behavioural and Stochastic Frontier Approaches. Applied Economics. 26:181- 88. http://dx.doi.org/10.1080/00036849400000074

AMAZA, P. S.- MAURICE, D. C. 2005. Identification of factors that influence Technical Efficiency in Rice-based Production Systems in Nigeria. Paper presented at Workshop on Policies and Strategies for Promoting Rice Production and Food Security in Sub-Saharan Africa: 7-9 November, 2005, Cotonou (Benin). Available at: http://www.warda.cgiar.org/workshop/ricepolicy/Amaza/ Amaza.Nigeria.paper.pdf

BATTESE, G.E. 1997. A note on the estimation of Cobb-Douglas Production Functions when some explanatory variables have zero values. Journal of Agricultural Economics, 48: 250-252. http://dx.doi.org/ 10.1111/j.1477-9552.1997.tb01149.x

BATTESE, G.E.- COELLI, T. J. 1995. A Model for Technical Inefficiency effect in Stochastic Frontier Production function for Panel Data. Empirical Economics, 20, 325-332. http://dx.doi.org/10.1007/BF01205442

BEGUM, I.A.- BUYSSE, J.- ALAM, M. J.HUYLENBROECK, G. V. 2009. An application of Data Envelopment Analysis (DEA) to evaluate Economic Efficiency of Poultry Farms in Bangladesh, Paper presented at the International Association of Agricultural Economists Conference, Beijing, China, August 16 -22. http://ageconsearch.umn.edu/bitstream/50900/2/IAAE_I D\%20437.pdf

CHOWDHURY, N.T. 2013. The Relative Efficiency of Hired and Family Labour in Bangladesh Agriculture. $J$. Int. Dev.. http://dx.doi.org/10.1002/jid.2919

COELLI, T.J., 1995a, Recent Development in Frontier Modeling and Efficiency Measurement. Australian 
Journal of Agricultural Economics, 39, 215-245. http://dx.doi.org/10.1111/j.1467-8489.1995.tb00552.x

COELLI, T., 1996a, Specification and Estimation of Stochastic Frontier Production Functions. Unpublished Ph.D. Dissertation, University of New England, Australia.

COELLI, T., 1996b, Frontier Version 4.1: A Computer Program for Stochastic Frontier Production and Cost Function Estimation. Working Paper 96/7, Center for Efficiency and Productivity Analysis, Department of Econometrics, University of New England, Armidale, Australia.

COELLI, T. J.- BATTESE, G. 1996. Identification of Factors which influence the Technical Inefficiency of India Farmers. Australian Journal of Agricultural Economics, 40, pp. 103-128. http://dx.doi.org/10.1111/j.1467-8489.1996.tb00558.x DZENE, R. 2010. What drives Efficiency on the Ghanaian Cocoa Farm? Ghana Institute of Management and Public Administration, Accra, Ghana.

EFFIONG, E. O.- ONYENWEAKU, C. E. 2006. Profit Efficiency in Broiler Production in Akwa Ibom State, Nigeria. International Journal of Agriculture and Rural Development, 7(1):72-79.

http://dx.doi.org/10.4314/ijard.v7i1.2621

EGBETOKUM, O. - AJIJOLA, S. 2008. Technical Efficiency of Cowpea Production in Osun State, Nigeria, Continental Journal of Agricultural Economics 1: 32-37. http:/www.wiloludjournal.com/pdf/agecons/2008/32$\underline{\text { 37.pdf }}$

FARELL, M. J. 1957. The measurement of Productive Efficiency. Journal of the Royal Statistical Society. A. General,120,3,pp.253-81.

http://dx.doi.org/10.2307/2343100

IKE, P.C.- UGWUMBA, C. O. A. 2011. Profitability of Small Scale Broiler Production in Onitsha North Local Government Area of Anambra State, Nigeria. International Journal of Poultry Science, 10 (2): 106109. http://dx.doi.org/10.3923/ijps.2011.106.109

KODDE, D. - PALM, F. 1986. Wald Criteria for Jointly Testing Inequality Restrictions, Econometrica 54, 1243 1248. http://dx.doi.org/10.2307/1912331

KUMBHAKAR, S. C. 2001. Estimation of Profit Functions When Profit Is Not Maximum. American Journal of Agricultural Economics, 83 (1), 1-19. http://dx.doi.org/10.1111/0002-9092.00133

KUMBHAKAR, S.C.- BISWAS, B. - BAILEY, D. V. 1989. A study of Economic Efficiency of Utah Dairy Farmers: A system approach. Review of Economics and Statistics, 71: 595-604. http://dx.doi.org/10.2307/1928101 MOFA (2010). Fact Sheet, Statistics, Research and Information Directorate (SRID), December, 2010

MUSA, Y. H.- ONU, J. I.- VOSANKA, I. P. ANONGUKU, I. 2011. Production efficiency of yam in Zing Local Government Area of Taraba State, Nigeria. Journal of Horticulture and Forestry, 3(12):372-378. http://www.academicjournals.org/journal/JHF/articleabstract/C12776B1939

NKANSALA, K. O. 2004. Chapter on Ghana, in Ghana Agricultural Workers Union (QAWA) et al (2004).
OHAJIANYA, D.O. 2005. Economic efficiency among small scale poultry farmers in Imo State, Nigeria, A stochastic Frontier Production Model Approach. International Journal of Agriculture and Rural Development, 6:19-25.

http://dx.doi.org/10.4314/ijard.v6i1.2584

ONUMAH, E.E.- BRÜMMER, B.- HÖRSTGENSCHWARK, G. 2010. Elements which delimitate Technical Efficiency of fish farms in Ghana. Journal of the World Aquaculture Society, 4(41): 506 - 518. http://dx.doi.org/10.1111/j.1749-7345.2010.00391.x

PEPRAH J. A. 2010. Access to Credit and Technical Efficiency of Vegetable Growers in Mfantsiman District of Ghana. Available at: http://www.ssrn.com/abstract $=1805218$

RANDON, M. E.- ASHITEY, E. 2011. Poultry and Products Brief Annual, Global Agricultural Information Network Report, USDA Foreign Agricultural Services. Available at: http://gain.fas.usda.gov/Recent $\% 20$ GAIN $\% 20$ Publicatio ns/Poultry $\% 20$ and $\% 20$ Products $\% 20$ Brief $\% 20$ Annual_Ac cra Ghana 10-7-2011.pdf

RAHMAN, S. 2003. Profit Efficiency among Bangladeshi Rice farmers, Food Policy 28: 487-503. http://dx.doi.org/10.1016/j.foodpol.2003.10.001

SCHMIDT, G. S. 2008. The effect of Broiler Market Age on the Performance Parameters and Economics Revista Brasileria de Ciencia Avicola, 4(10):223-225. Available at:

$<\underline{\text { http://www.scielo.br/pdf/rbca/v10n4/a05v10n4.pdf }>}$ SEIDU, A. 2008. Technical Efficiency of Rice Farmers in Northern Ghana, AERC Research Paper, 178. Available

http://dspace.africaportal.org/jspui/bitstream/123456789/ 32327/1/RP178.pdf?1

TZOUVELEKAS, C. J.- PANTZIOS, FOTOPOULOS, C. 2001. Technical Efficiency of Alternative Farming Systems: The Case of Greek Organic and Conventional Olive-Growing Farms. Journal of Food Policy. 26: 54969. http://dx.doi.org/10.1016/S0306-9192(01)00007-0

WADUD, A.- WHITE, B. 2000. Farm Household efficiency in Bangladesh: A Comparison of stochastic frontier and DEA methods. Applied Economics 32:16651673. http://dx.doi.org/10.1080/000368400421011

WANG, J.- CRAMER, G. L.- WAILES, E. J. 1996. Production efficiency of Chinese agriculture: Evidence from rural household survey data. Agricultural Economics 15:17-28.

http://www.sciencedirect.com/science/article/pii/S01695 $\underline{15096011929}$ 